\title{
Projetos políticos na revolução constitucionalista na Bahia (1821-1822)
}

Political Projects in the

Constitucionalist Revolution (Bahia,

1821-1822)

\section{Argemiro Ribeiro de Souza Filho \\ Doutorando em História pela \\ Universidade de São Paulo}

\section{Resumo}

Parte inerente da crise sistêmica que convulsionava o Antigo Regime português, a Bahia recebeu com entusiasmo as notícias sobre a Revolução Liberal do Porto (1820). A partir de então, verificou-se na capital (Salvador) variadas ações políticas, cujos objetivos mais explícitos visavam assegurar a rápida e decisiva adesão ao sistema constitucional. Atentos aos pressupostos liberais, distintos segmentos sociais se posicionaram contra o governo absoluto e, em fevereiro de 1821, proclamaram a Revolução Constitucionalista vinculando, assim, a província baiana às "Cortes Gerais, Extraordinárias e Constituintes da Nação Portuguesa". 0 artigo discute como a efervescência política do constitucionalismo na Bahia propiciou a elaboração de projetos liberais distintos, possibilitando, inclusive, a participação política das classes populares em um contexto revolucionário cujos horizontes ainda estavam para ser definidos.

\section{Abstract}

Part of the systemic crisis of the Portuguese Ancien Regime, Bahia received with enthusiasm the news on the Porto Liberal Revolution (1820). From then on, a number of political actions occurred in the capital (Salvador), which aimed mainly to reassure a fast and decisive adhesion to the constitutional system. Observing the liberal discourse, different social segments positioned themselves against the absolute government and, in February 1821, proclaimed the Revolution Constitutionalist linking, thus, the Bahian Province to the "General, Extraordinary and Constituents Courts of the Portuguese Nation". The article focuses on how the constitutional political turmoil favored the elaboration of distinct liberal projects, making possible the political participation political of the popular classes in a revolutionary context whose horizons were still to be defined.

\section{Palavras-chave}

Bahia, constituição, história política, homens livres pobres

\section{Keywords}

Bahia, constitution, political history, poor free people 
Devassa de escritos inflamatórios e Sediciosos encontrados em mãos de João Crioulo, escravo de Antonio José Pereira Rocha, e Francisco Antonio de Souza. Cópias de devassas - processos datilografados. APEB. Seção Colonial e Provincial. Ano: 1821-1823. Maço: 6023. Sobre 1798, ver JANCSÓ, István. Na Bahia, contra o Império: História do ensaio de sedição de 1798. São Paulo: Hucitec; Salvador: EDUFBA, 1996.

Devassa de escritos inflamatórios e Sediciosos.. Op.Cit., Maço: 6023. (Grifos meus).

3

A Junta de Governo Provisória da Bahia contou com os seguintes representantes: do clero o reverendo deão José Fernandes da Silva Freire; da milícia os tenentes-coronéis Francisco de Paula e Oliveira e Francisco José Pereira; do comércio, Francisco Antonio Filgueiras e José Antonio Rodrigues Vianna; da agricultura, Paulo José de Melo. Para presidente foi, do mesmo modo, escolhido pela parte da cidade o desembargador da Relação da Bahia, Luiz Manoel de Moura Cabral e, finalmente, como secretários José Caetano de Paiva e José Lino Coutinho. SILVA, Ignácio Accioli de Cerqueira e. Memórias Históricas e Politicas da Provincia da Bahia. Anotado por Braz do Amaral. Bahia: Imprensa Oficial do Estado, 1919-1931. 3v. p.272-273. Convém observar que entre os integrantes da Junta havia naturais tanto de Portugal quanto da Bahia.
No dia 7 de dezembro de 1821, uma sexta-feira, foram encaminhados à cadeia da cidade de Salvador o preto João Crioulo, escravo de Antonio José Pereira da Rocha, e o pardo Francisco Antonio de Souza. Embora encarceramentos de cativos e pessoas livres de cor não constituissem novidade no Brasil escravista, as reclusões de João e Francisco tinham motivações outras que não as de ordem sociais. Deviam-se às suas práticas políticas. À semeIhança dos envolvidos com o ensaio de sedição ocorrido na Bahia em 1798, ambos foram mandados à prisão sob a alegação de portarem e divulgarem "escritos infamatórios e sediciosos" contra as autoridades constituidas, sendo denunciados pela veiculação de três documentos produzidos com "o fim de amotinar, ou ao menos, aterrar os Povos". 10 primeiro destes escritos constituia uma "Proclamação assinada por João Primo" e datada de 3 de novembro de 1821; o segundo, dizia-se constar a mesma caligrafia, trazia a data 14 do referido mês e era intitulado: "Cidadãos beneméritos e verdadeiros Constitucionais respondem às fabulosas Proclamações dos agonizantes Bachás! SENHORES DÉSPOTAS DO NOVO MODELO!". Subscreveu-Ihe: "os Amantes do bem público" e, finalmente, o terceiro tratava-se de uma carta dirigida, em $1^{\circ}$ de dezembro, "aos Observadores e Célebres Constitucionais". 2 Adiante, afirmaria uma testemunha que outros exemplares dos papéis confiscados tinham aparecido dispersamente na capital baiana sem se saber, ao certo, quem eram seus autores ou mesmo as pessoas que os davam publicidade. Em termos legais, isso ocorreu quando o comerciante matriculado, Manoel José Dias Correia, branco de 29 anos, morador na Cidade-Baixa, conduziu à presença dos membros da Junta Provisória de Governo da Bahia o escravo João e os textos mencionados. De qualquer forma, as autoridades locais viram-se obrigadas a redobrar as atenções sobre o que acontecia na província.

Analisemos melhor o contexto destas prisões. Em 1821 não somente a Bahia mas todo o Império português experimentava profundas e céleres transformações políticas. No ano anterior a Revolução Liberal havia triunfado no Reino de Portugal destituindo os principais representantes do Antigo Regime português e substituindo-os por autoridades que juraram obedecer a constituição da Espanha enquanto outra carta de lei seria, em breve, discutida e aprovada pelas "Cortes Gerais, Extraordinárias e Constituintes da Nação Portuguesa". Na expectativa de renegociar um novo pacto político que thes assegurasse funções mais proeminentes no interior do Império, a Bahia instalara o seu processo revolucionário em 10 de fevereiro de 1821. Naquele momento, a província optou pela ruptura política e financeira com a corte joanina sediada no Rio de Janeiro e simultaneamente comunicou as autoridades de Portugal a sua disposição para adotar os mesmos princípios que fossem acordados no Soberano Congresso. Em conformidade com o movimento liberal português, uma Junta Provisória de Governo composta por sete representantes do clero, da milícia, do comércio, da agricultura e da cidade, fora escolhida pelos membros da Câmara Municipal e, em seguida, aprovada pelo povo e pela tropa reunidos na Praça Municipal em frente do prédio camarário e Palácio do Governo. ${ }^{3} \mathrm{~A}$ província do Pará havia também experimentado, em $1^{\circ}$ de janeiro de 1821 , um conjunto de fenômenos análogos ao da Bahia e, a 26 de fevereiro, no Rio de Janeiro, d. João VI viu-se obrigado a jurar a constituição espanhola e, antecipadamente, a que viesse a ser elaborada nas Cortes lisboeta. Com isso, rapidamente todo o processo de vinculação às autoridades constitucionais foi confirmado na América portuguesa permitindo, em contrapar- 
Cf. JANCSÓ, István (Org.). Independência: história e historiografia. São Paulo: Hucitec; Fapesp, 2005; _____ (Org.). Brasil: formação do Estado e da Nação. São Paulo: Hucitec; Ed. UNIJUÍ; Fapesp, 2003. Ver também, NOVAIS, Fernando Antonio; MOTA, Carlos Guilherme. A independência politica do Brasil. 2. ed. São Paulo: Hucitec, 1996. p. 18.

5

Cf. AUFDERHEIDE, Patrice Ann. Order and violence: social deviance and social control in Brasil (1780-1840). These. (These de Doctorat), University of Minnesota, Minnesota, 1976; MORTON, F. W. O. The Consertative Revolution of Independence: Economy, society and politics in Bahia (1790-1840). Thesis Submitted to the Board of the Faculty of Modern History in Partial Fulfilment of the Requirements for the Degres of D. Phil, University of Oxford, Oxford, 1974; REIS, João José. A elite baiana face os movimentos sociais, Bahia: 1824-1840. Revista de História. São Paulo, Out-dezembro, v. LIV, n. 108, ano XXVII, p. 341-384, 1976;

Rebelião escrava no Brasil: a história do levante dos malês em 1835. Edição rev. e amp. São Paulo: Companhia das Letras, 2003. Ver também: GUERRA FILHO, Sérgio Armando Diniz. O povo e a Guerra: Participação das camadas populares nas lutas pela Independência do Brasil na Bahia. Dissertação (Mestrado em História) Universidade Federal da Bahia, Salvador, 2004; SOUZA FILHO, Argemiro Ribeiro de. A Guerra de Independência na Bahia: Manifestações politicas e violência na formação do Estado nacional (Rio de Contas e Caetité). Dissertação (Mestrado em História), Faculdade de Filosofia, Letras e Ciências Humanas, Universidade Federal da Bahia, Salvador, 2003 e KRAAY, Hendrik. Muralhas da independência e liberdade do Brasil: a participação popular nas lutas políticas (Bahia, 1820-1825). In: MALERBA, Jurandir (Org.). A independência brasileira: novas dimensões. Rio de Janeiro: Ed. FGV, 2006. p. 303-341.

De maneira geral, dentre os principais estudos que analisam o impacto desses movimentos na capitania/provincia da Bahia, destacam-se: SILVA, Eduardo; REIS João José. 0 jogo duro do dois de Julho: o "Partido Negro" na Independência da Bahia. In: Negociação e conflito: a resistência negra no Brasil escravista. São Paulo: Companhia das Letras, 1989. p. 79-98; JANCSÓ, István. Na Bahia, contra o Império: História do ensaio de sedição de 1798. São Paulo: Hucitec; Salvador: EDUFBA, 1996; WISIAK, Thomas. A 'Nação partida ao meio': tendências políticas na Bahia na crise do Império luso-brasileiro. Dissertação (Mestrado em História) - Universidade de São Paulo, São Paulo, 2001; e TAVARES, Luis Henrique Dias. Da Sedição de 1798 à Revolta de 1824 na Bahia: Estudos sobre a Sedição de 12 de agosto de 1798. Salvador: Edufba; São Paulo: Unesp, 2003 e _-__. Independência do Brasil na Bahia. Salvador: Edufba, 2005. Sobre as práticas antilusitanas, conhecidas como mata-marotos, ocorridas no Alto Sertão da Bahia, ver SOUZA FILHO, Argemiro Ribeiro de. Op.Cit., p.202-208.

Para maior compreensão da crise do Antigo Regime português, ver NOVAIS, Fernando Antonio. Portugal e Brasil na crise do Antigo tida, que projetos políticos variados postulassem a disputa sobre o futuro das suas comunidades.

Desse modo, a prisão do escravo João Crioulo e do pardo Francisco Antonio correspondia à manifestação política de um tipo de rivalidade entre projetos, pois, em principios de novembro de 1821, parte dos habitantes da província baiana já reunia fortes motivos para desconfiar dos rumos que 0 pacto constitucional, controlado por uma maioria de deputados nascidos e eleitos por Portugal, podia tomar. No plano provincial, as atitudes da Junta Governativa na firme defesa dos interesses dos grandes comerciantes portugueses estabelecidos na capital havia não somente suscitado discórdias, como provocou uma malograda tentativa de deposição e substituição de todos os membros do governo. Questões que serão mais detidamente examinadas adiante. Por ora, acredito ser importante tecer algumas considerações sobre como a derrocada do Antigo Regime português abriu novas e fecundas oportunidades políticas tanto para a província baiana quanto para o conjunto da América portuguesa.

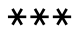

Nos últimos anos, estudos têm sido desenvolvidos com ênfase no processo de construção do Estado e da nação brasileiros, evidenciando o quanto esse movimento resultou de um conjunto de fenômenos de grande complexidade. ${ }^{4} \mathrm{Em}$ se tratando especificamente da província da Bahia, os estudos recentes têm sustentado que os anos anteriores e posteriores à Guerra de Independência (1822-1823) foram marcados por profundas agitações político-sociais acompanhadas, na maior parte das vezes, por distúrbios violentos que envolveram lusitanos e os naturais da América portuguesa. Registrou-se ainda que a incidência de saques, de motins militares e de revoltas de escravos e homens livres intensificou-se naqueles anos. ${ }^{5}$

De fato, a singularidade político-social da Bahia, cuja relevância no período pode ser mensurada, principalmente, pelo ensaio de sedição de 1798, na adesão ao movimento constitucionalista de 1821, no Levante dos Periquitos (1824) e nas manifestações antilusitanas, denuncia ter existido ali uma constelação saturada de tensões com intensos desdobramentos na conturbada conjuntura que antecedeu e sucedeu a independência. ${ }^{6}$

Em suma, o desmoronamento do Antigo Regime na América portuguesa e a formação do Estado e nação brasileiros (1821-1831) foram processos de complexa engenharia politica. Salienta-se, portanto, que em fins de 1820 e princípios de 1821 os habitantes das mais variadas províncias do Brasil viram franqueadas com a afirmação da Revolução Constitucionalista condições inéditas para expressarem todo o aprendizado político acumulado ao longo da crise do Antigo Regime português que, destes fins do século XVIII, atestava sua irredutibilidade. ${ }^{7}$ As notícias sobre os sucessos revolucionários no Reino de Portugal (1820) ao atravessarem o Atlântico, e independente da vontade daqueles que as propagavam, dinamizaram as alternativas politicas, culminando no desenlace do governo absoluto no Brasil.

Impetuosas, essas idéias liberais polarizavam as forças políticas em face aos objetivos revolucionários, integrando, ainda que momentaneamente, o processo iniciado em Portugal aos desdobramentos sucedidos na América portuguesa. ${ }^{8}$ Em vista disso, as informações sobre a convocação das Cortes e a subseqüente divulgação e conhecimento das Bases da Cons- 
Sistema Colonial (1777-1808). 2. ed. São Paulo: Hucitec, 1983.

Cf. PRADO JÚNIOR, Caio. Evolução Política do Brasil. 6. ed. São Paulo: Brasiliense, 1966. p. 181183

Cf. BERNARDES, Denis Antônio de Mendonça. As novas condições da vida politica. In: _____. 0 patriotismo constitucional: Pernambuco, 18201822. São Paulo: Hucitec: Fapesp; Recife: Ed. Universitária da UFPE, 2006. p. 259-314. A citação encontra-se à página 269.

10

Sobre essas discussões nas Cortes lisboeta, ver BERBEL, Márcia Regina. A nação como artefato: deputados do Brasil nas cortes portuguesas (1821-1822). São Paulo: Hucitec, 1999 e WISIAK Thomas. Itinerário da Bahia na crise do Império luso-brasileiro (1821-1823). In: JANCSÓ, István (Org.). Independência: história e historiografia. São Paulo: Hucitec; Fapesp, 2005. p. 447-474. 11

Cf. SILVA, Ignácio Accioli de Cerqueira e. Memórias Históricas e Politicas da Província da Bahia. Anotado por Braz do Amaral. Bahia: Imprensa Oficial do Estado, v.2, p.267. Tanto o Reino de Portugal como as nações espanholas e francesas experimentavam, neste período, uma fase de profunda depressão econômica. Inevitavelmente, essa situação tinha incidência direta nos rumos do comércio português no Brasil já fragilizado com a abertura dos portos e a entrada em vigor do Tratado de Aliança e Amizade (1810) com a Inglaterra, ainda mais poderosa após o destroçamento do exército napoleônico em 1815. Em influentes zonas portuárias da América portuguesa, como era a cidade de Salvador em princípios do Oitocentos, a concorrência crescente do comércio inglês vinha tornando-se tão acentuada que, em alguns casos, podia-se até dispensar os produtos lusitanos, dai a animação manifesta entre os negociantes portugueses com as promessas políticas suscitadas pela Revolução do Porto. Encontrando-se em Salvador em fevereiro de 1821, Sierra y Mariscal posteriormente anotou: "Ao monstruoso tratado de 1810, se deve atribuir em grande parte, e como causa imediata a Revolução do Brasil. Depois deste tratado, eu tenho visto nas vizinhanças do Rio de Janeiro, vilas reduzidas a ruínas, e desertas; o mesmo acontece no Recôncavo da Bahia". SIERRA y MARISCAL, Francisco de. Idéias gerais sobre a Revolução do Brasil e suas conseqüências. Anais da Biblioteca Nacional, Rio de Janeiro, v.43-44, p.51-81, 1931, p. 56. Para o contexto mais geral do Brasil frente às revoluções liberais no Ocidente, ver. GODECHOT, Jacques. Independência do Brasil e a Revolução do Ocidente. In: MOTA, Carlos Guilherme. (Org.). 1822: Dimensões. São Paulo: Perspectiva, 1972. p.27-37 e MAURO, Frédéric. A Conjuntura Atlântica e a Independência do Brasil. In: MOTA Carlos Guilherme (Org.), op. cit., p. 38-47.

12

Emblemático, nesse sentido, foi atuação política do cirurgião Cipriano José Barata de Almeida, cuja biografia foi bem traçada em um estudo ainda recente.MOREL, Marcos. Cipriano Barata na Sentinela da Liberdade. Salvador: Academia de Letras da Bahia, Assembléia Legislativa do Estado da Bahia, 2001. tituição Política da Monarquia Portuguesa passaram a constituir "o eixo de referência" para o conjunto do Império português. ${ }^{9}$

Na Bahia, a difusão das notícias envolvendo a queda da Regência e convocação das Cortes Gerais foi recebida com expectativas. A partir de então as reuniões em locais públicos tornaram-se concorridas. Por certo, despertava a atenção saber como o liberalismo português definiu e estendeu aos demais habitantes do Império os mecanismos garantidores do direito à representação política, como seriam regulados os poderes régios e, sobretudo, deviam suscitar fortes interesses compreender quais seriam os demais direitos e deveres políticos inalienáveis e que, por isso mesmo, não deveriam ficar de fora da Constituição a ser elaborada. ${ }^{10}$

Dentre os entusiasmados com as transformações no Ultramar, encontraram-se os comerciantes portugueses. ${ }^{11}$ Mas não apenas eles. Ainda no topo da hierarquia social baiana, magistrados e militares - os quais também aspiravam por reformas - saudaram os novos acontecimentos. Para alguns dos sobreviventes de 1798, cujas evidências apontavam para o comprometimento com a contestação direta ao governo absoluto português, as perspectivas devem ter sido bastante inspiradoras. ${ }^{12}$ Nem mesmo d. Francisco de Assis Mascarenhas, conde da Palma, esboçou reação que se podia aguardar de um governador capitão-general (1818-1821). Logo, porém, os descontentamentos chegaram ao conhecimento de d. João VI e da corte instalada no Rio de Janeiro. Considerado o ministro mais influente junto a el-rei, Tomás Antonio Vilanova Portugal propôs a substituição do governo baiano por um militar de prestígio e confiança na tropa. ${ }^{13}$ Ao ter consciência deste fato, o conde manteve-se impassivel, nem mesmo o desprestígio prenunciado parecia incomodá-lo. Pari passu, as tropas de linha e as milicias colocaram-se em estado de alerta.

Apesar dos descontentamentos manifestos, o ambiente suscitado pelas festas religiosas celebradas na capital baiana, cujo ápice ocorria justamente entre os meses de dezembro e janeiro, pareceu retardar a efetivação de projetos favoráveis à mudança do regime político na América portuguesa. ${ }^{14}$ Normalmente, os recessos na administração e alfândega transcorriam em um intervalo de dias determinados a partir daqueles marcos temporais. Esses dias eram de lazer, de descanso. $E_{1}$ em condições como essas, era comum ocorrer um relaxamento tácito na disciplina, inclusive o próprio controle privado sobre os escravos tornava-se menos rígido. ${ }^{15}$ Assim, seja para as classes dominantes, seja para as intermediárias, àquele periodo poderia não parecer o mais propício a consertar grandes alterações políticoadministrativas. Nesse sentido, não se constitui exagero pensar que idiossincrasias culturais possam ter contribuido para que o governo absoluto, embora condenado, prosseguisse na Bahia por um intervalo de tempo já difícil de ser aproveitado pela Coroa portuguesa, a qual, sem muito conseguir fazer, via esboroar a operacionalidade das formas consagradas de sua legitimidade política.

Em se tratando, por exemplo, dos estrangeiros pouco habituados à capital baiana, os códigos comportamentais partilhados entre determinados grupos sociais poderiam ser mal-interpretados e adquirirem, por isso, outros significados. Esse parece ter sido o caso do cônsul da França na Bahia, Jacques Guinebaud, que ao registrar o conjunto de procedimentos políticosociais dos habitantes de Salvador entre fins de 1820 e princípios do ano seguinte afirmava: 
Cf. VARNHAGEN, Francisco Adolfo de.

Provincias: Bahia. In: _____. História do Independência do Brasil: Até ao reconhecimento pela antiga metrópole compreendendo, separadamente, a dos sucessos ocorridos em algumas provincias até essa data. Anotada pelo Barão de Rio Branco e por uma comissão do Instituto Histórico e Geográfico Brasileiro. 4. ed. Revisada e anotada pelo Prof. Helio Vianna. São Paulo: Melhoramentos, 1957. p. 23.

14

Oficialmente católico - mas também adaptado às tradições das comunidades africanas -, 0 calendário religioso, com seu grande ciclo festivo, atingia o auge entre o último e primeiro mês do ano. Em dezembro, comemoravam-se Santa Bárbara (04), Nossa Senhora da Conceição (08), Santa Luzia (13) e o Natal (25). Em janeiro, no Ano-Novo $\left(1^{\circ}\right)$ ocorria a procissão marítima em louvor ao Senhor dos Navegantes; seguiam-se depois o Dia de Reis (06), a festa do Senhor do Bonfim (segundo domingo do mês) e o Entrudo. Segundo o calendário litúrgico, para os anos de 1821 e 1822 o Entrudo deveriam acorrer, respectivamente, nos dias 4 a 6 de março e 17 a 19 de fevereiro. Cf. MATTOSO, Kátia M. de Queirós. Bahia, século XIX: uma província no Império. Rio de Janeiro: Nova Fronteira, 1992. p. 205. Agradeço ao Prof. Hendrik Kraay, da University of Calgary, no Canadá, que, com sugestivos pareceres, tem contribuido para que possamos aprimorar o presente estudo. Entre outras importantes informações, devo-Ihes o fornecimento das datas do Entrudo para os anos de 1821 e 1822

15

ARAÚJO, Ubiratan Castro de. A Guerra da Bahia Salvador: Ceao/UFBA, 2001 (Série Capitulos). p. 11.

16

Apud ARAÚJO, Ubiratan Castro de. Op.Cit., p.12. 17

Demonstrar como os grupos ou classes populares se posicionaram frente à desagregação do Antigo Regime português e ao processo subseqüente de independência do Brasil tem sido um campo de investigação ainda novo na historiografia. Dentre as iniciativas que têm buscado compreender o papel dos segmentos populares no cenário político dos anos de 1820, destacam-se as recentes pesquisas de Hendrik Kraay, segundo o qual: "Ainda se sabe muito pouco sobre a participação popular no processo de independência e como esta foi compreendida pelas classes populares. Ademais, a história da independência nas provincias do então Norte, notadamente a Bahia, mas também Pernambuco - onde a participação popular na política daqueles anos era mais visivel -, ainda permanece mal-incorporada às histórias da independência". KRAAY, Hendrik. Muralhas da independência e liberdade do Brasil: a participação popular nas lutas políticas (Bahia, 1820-1825). In: MALERBA, Jurandir (Org.). A independência brasileira: novas dimensões. Rio de Janeiro: Ed. FGV, 2006. p.307.

18

SILVA, Ignácio Accioli de Cerqueira e. Memórias Históricas e Políticas da Província da Bahia.

Anotado por Braz do Amaral. Bahia: Imprensa Oficial do Estado, v.2. p.267. Outros relatos contemporâneos distinguem a postura politica de
Muito se conspirou, mas, no geral, nota-se uma tranqüilidade e uma submissão à posição que adotará o rei, mesmo entre os mais radicais. Esta mudança de disposição deve-se ao medo que inspiravam os negros e os mulatos livres que já manifestaram o seu espírito de desordem, que deve inquietar os proprietários e os negociantes. ${ }^{16}$

Embora as classes dominantes e intermediárias pretendessem aguardar a melhor oportunidade para aderir ao movimento constitucional, as classes populares, formada predominantemente por negros e mulatos, poderiam ter motivos mais urgentes para acelerar e, finalmente, efetivar os planos de mudanças. Era preciso, então, levar em conta o alcance desses projetos pois ao demonstrarem descontentamento com a ordem vigente os proprietários e negociantes, bem posicionados no topo da hierarquia social, deveriam estar conscientes que nos colmos imediatos da pirâmide societária havia aqueles cujos reclamos eram mais incisivos. 0 interessante aqui é observar que na ante-sala da revolução liberal, os extratos sociais mais abastados agiam com cautela ante as manifestações públicas, especialmente porque as tentativas das classes populares em participar da gestão de projetos redefinidores do pacto político e social no interior da nação eram dados que precisavam ser considerados. ${ }^{17}$

Entre os sobrados da Rua da Praia, reduto comercial português, e a cadeia do Aljube, onde se encontravam presos alguns líderes da Revolução Pernambucana de 1817, sinuosos apresentaram-se os caminhos por onde se teceram planos contra o despótico governo. Radical de longa data, o cirurgião Cipriano José Barata de Almeida organizou "diversos Clubs", bem ao estilo da França de 1789, com o objetivo de tornar vitoriosas as idéias revolucionárias. ${ }^{18} \mathrm{~A}$ bibliografia e a documentação do período trazem também indicios de que as classes populares prosseguiram forcejando a velha ordem em favor de mudanças político-sociais profundas. Em dois meses, tanto se fez que o governador obtivera denúncia da conspiração. Os propósitos dos segmentos dirigentes foram, então, precipitados e, através de uma ampla aliança de classes, a Revolução Constitucionalista efetivou-se, em 10 de fevereiro de 1821, unindo a província da Bahia às Cortes Constituintes de Lisboa.

No alvorecer daquele dia, os revolucionários declararam os principios de procedimentos tão extraordinários. Mencionando indiretamente o monarca, taxaram as decisões do Rio de Janeiro como traição à Bahia lembrando que os males e motivos passados em Portugal eram bem conhecidos também na província. $E_{1}$ assim, condenaram a política dispensada à agricultura, ao comércio e à navegação. Em seguida, a crítica recaiu sobre "violentos tributos arbitrados, corrupção dos magistrados, pobreza dos povos, misérias dos soldados e toda a casta de opressão, despotismo e tirania".19 Essa gradação dos motivos ajuda-nos a entender a amplitude da aliança de classe necessária para por termo ao Antigo Regime. ${ }^{20}$ Ao registrar a "pobreza dos povos", o manifesto fundador da Revolução Constitucionalista na Bahia deixava evidente a importância daquele numeroso estrato para os rumos da sociedade escravista.

Decerto, a busca de alternativas políticas para superação da crise do Antigo Regime português na Bahia não se constituiu em um movimento circunscrito às classes dominantes e intermediárias com acessos e facilidades ao mundo letrado. Se, por um lado, a Revolução Constitucionalista agregou comerciantes portugueses, senhores de engenho, traficantes de escravos, militares de médio e alto escalões, profissionais liberais e homens 
Cipriano Barata como o fautor das conspirações para a tomada do governo provincial, a ponto de um defensor do Antigo Regime, sequioso por atestar o espírito subversivo na Bahia no período, recomendar a leitura crítica dos "papéis [...] do Sanscolote [sic] Barata". SIERRA y MARISCAL, Francisco de. Idéias gerais sobre a Revolução do Brasil e suas conseqüências. Anais da Biblioteca Nacional, Rio de Janeiro, v.43-44. p.59.

19

Apud SILVA, Ignácio Accioli de Cerqueira e. Memórias Históricas e Politicas da Provincia da Bahia. Anotado por Braz do Amaral. Bahia: Imprensa Oficial do Estado, v.3. p.268-269. 20

A rigor, essa heterogeneidade de interesses não era uma invenção baiana já que estava totalmente de acordo com a conduta do movimento

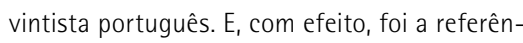
cia para as adesões subseqüentes que se verificaram em diversas partes do Brasil em 1821.

\section{1}

Sobre as formas variadas de percepção da crise do Antigo Regime português na América e os projetos politicos que se propunham superála, ver JANCSÓ, István; PIMENTA, João Paulo Garrido. Peças de um mosaico (ou apontamentos para o estudo da emergência da identidade nacional brasileira). In: MOTA, Carlos G. (org.) - Viagem incompleta: a experiência brasileira (1500-2000). São Paulo, Senac, 2000.

22

A hegemonia da classe senhorial iria se concretizar com a formação e a consolidação do Estado e nação brasileiros, como foi assinalado em NOVAIS, Fernando Antonio; MOTA, Carlos Guilherme. A independência politica do Brasil. 2. ed. São Paulo: Hucitec, 1996.

23

SILVA, Ignácio Accioli de Cerqueira e. Op.Cit., p. 275 . da Igreja, por outro, teve que aceitar a participação das classes populares, cujo grau de formação ou mesmo suas identidades pessoais eram, na maior parte dos casos, simplesmente desconhecidos. Razão pela qual, as expressões "Tropa e Povo" deveriam exprimir, com propriedade, a sobrepujança desses segmentos que, coesos, garantiam e davam respaldo moral a uma transformação política daquela magnitude.

Depreende-se, assim, que a concretização de um projeto para superação da crise do Antigo Regime colocou-se para muitos contemporâneos a necessidade de compreender, ou ainda redefinir e levar adiante, uma série de termos que, a partir de então, ampliava o espaço da política no continente do Brasil. Constitucionalismo, soberania, representação e nação seriam algumas dessas concepções que, pouco a pouco, acabariam por transmudar a própria idéia de independência, tornando factível a formação de um Estado nacional.

Ao promoverem o alinhamento da província baiana às Cortes de Lisboa o movimento constitucionalista permitiu que a província passasse a contribuir de maneira mais incisiva para o rápido aceleramento de um processo histórico que marcaria profundamente os horizontes políticos de Brasil e Portugal. Como a percepção da crise do Antigo Regime não se deu de modo uniforme para os homens e mulheres que integravam o Império lusobrasileiro, ${ }^{21}$ as primeiras proposituras para a superação do poder absoluto na Bahia denunciam a existência de fissuras internas, exigindo dos novos dirigentes posições firmes com vistas a controlar os anseios da população. Além do mais, dada o caráter compósito dos envolvidos com o movimento, os mecanismos que visaram regulamentar a participação dos segmentos de baixa condição tornaram-se essenciais para assegurar a supremacia da classe senhorial, ainda em fase de organização. ${ }^{22}$

Conforme dito anteriormente, os debates sobre os rumos e a estruturação da Junta Governativa ocorreram no interior da Câmara Municipal de onde saíram os nomes dos novos governantes da província a serem imediatamente confirmados pelas saudações do povo e tropa reunidos. Todavia, essa forma de escolha das novas autoridades, confirmada por gestos pelos que estavam do lado de fora do prédio camarário, não satisfez uma parcela significativa dos envolvidos. Em conseqüência, parte dos descontentes irrompeu a inédita sessão "gritando em altas vozes no meio de aclamações e de vivas que queria também por membro do governo o tenente-coronel Manuel Pedro de Freitas Guimarães", o qual, na madrugada daquele mesmo dia 10 de fevereiro de 1821, estivera no comando da tropa de artilharia em favor da revolução. ${ }^{23}$ Não obstante a exigência ter sido acatada, os rumos posteriores dos acontecimentos políticos pareciam indicar que, pelo desejo das autoridades constituídas, a participação dos segmentos subalternos deveria restringir-se ao âmbito institucional sob a direção das classes dominantes. Todavia, a conjuntura político-social na capital baiana nos meses posteriores evidencia que houve fortes resistências neste sentido.

\section{Projetos divergentes na Revolução Constitucionalista}

A adesão da Bahia à Revolução Constitucionalista elevou a percepção entre os habitantes da província de que a crise do Antigo Regime possuía significados variados. Para muitos contemporâneos passou a ser cada vez mais importante não apenas identificar a forma como os protagonistas em cena tomavam partido por uma determinada causa política, mas também interessava perceber o quanto poderiam concorrer pela sua realização. Essa 
24

ARAÚJO, Ubiratan Castro de. A Guerra da Bahia Salvador: Ceao/UFBA, 2001 (Série Capitulos). p.25.

\section{5}

Ibidem, p.29-30. Para uma análise mais geral sobre o tema, ver KRAAY, Hendrik. Identidade racial na política, Bahia, 1790-1840: o caso dos henriques. In: JANCSÓ, István (Org.). Brasil: formação do Estado e da Nação. São Paulo: Hucitec; Ed. Unifuí; Fapesp, 2003. p.521-546. 26

A esse respeito, caberia a el-rei pronunciar-se sobre o requerimento em que o "coronel e mais oficiais do $3^{\circ}$ regimento de milícias dessa cidade [Salvador], pedem permissão para fazerem fardas azuis para o serviço diário, à imitação das que usam os caçadores vindos de Lisboa". APEB. Seção Colonial e Provincial. Ano: 1816. Maço: 118.

27

KRAAY, Hendrik. Op.Cit.

28

Composta por dois batalhões de infantaria e uma companhia de artilharia, a expedição militar apresentou-se, em 23 de agosto de 1821, às autoridades da Bahia com a designação de Legião Constitucional Lusitana. SILVA, Ignácio Accioli de Cerqueira e. Memórias Históricas e Políticas da Provincia da Bahia. Anotado por Braz do Amaral. Bahia: Imprensa Oficial do Estado, v.3, p.281 e 287, nota 21.

29

Para o contexto político do Centro-Sul que possuía no Rio de Janeiro o seu centro irradiador, ver VARNHAGEN, Francisco Adolfo de. Províncias: Bahia. In:_____. História da Independência do Brasil: Até ao reconhecimento pela antiga metrópole compreendendo, separadamente, a dos sucessos ocorridos em algumas províncias até essa data. Anotada pelo Barão de Rio Branco e por uma comissão do Instituto Histórico e Geográfico Brasileiro. 4. ed. Revisada e anotada pelo Prof. Helio Vianna. São Paulo: Melhoramentos, 1957. ARMITAGE, John. História do Brasil: desde o período da chegada da família de Bragança, em 1808 até a abdicação de D. Pedro I, em 1831, compilada à vista dos documentos públicos e outras fontes originais formando uma continuação da história do Brasil, de Southey. Belo Horizonte: Itatiaia; São Paulo: Edusp, 1981. tendência se agravou à medida que uma parte da população começou a ter dúvida sobre a conduta das Cortes lisboeta para com o Brasil. Em maio de 1821, o cônsul Guinebaud informava ao governo francês que as tropas militares da capital baiana estavam em estado de mobilização após ter sido divulgado que os deputados liberais portugueses conseguiram a aprovação de medidas contrárias à liberdade comercial para o Brasil. ${ }^{24}$

No plano militar, oficiais e soldados nascidos na América portuguesa - a maior proporção dos quais homens mulatos e pardos - observavam consternados o fato de os seus pares europeus terem alcançados as melhores promoções em reconhecimento ao apoio decisivo que a tropa prestou ao sucesso da Revolução Constitucionalista. Convêm realçar que os ressentimentos entre os militares do Brasil em relação às tropas de Portugal não eram necessariamente novos. Após ter lutado nas guerras napoleônicas e peninsulares, entretendo-se com o paradigma do soldado-cidadão, com engajamentos em um exército nacional politizado pelos ideais da Revolução Francesa, parte dos contingentes militares enviados de Lisboa para combater os revolucionários pernambucanos de 1817 ficou estacionado em Salvador. ${ }^{25}$ Afastada do velho continente, a tropa lusitana parecia sentir necessidade de se auto-afirmar com gestuais exuberantes frente aos filhos da terra, a começar pelos novos uniformes que traziam da Europa. Para tentar corrigir certas diferenciações em uma corporação que deveria ser reconhecida pelo alinhamento, disciplina e compostura, em 10 de setembro de 1816, o coronel e mais oficiais do regimento dos Henriques chegaram a requisitar que a Coroa Ihes providenciasse fardamentos iguais aos usados pelos regimentos de caçadores vindos de Lisboa. ${ }^{26}$ Havia, de fato, uma tendência à discriminação fundada em critérios raciais exercida pelos soldados lusitanos sobre os homens da terra. ${ }^{27}$ Essa era, a rigor, a questão de fundo entre os militares e que se tornara mais evidente à medida que as prerrogativas necessárias ao exercício da cidadania passaram a ser referência obrigatória para os homens livres nascidos no Império português.

As animosidades na caserna podiam ser interpretadas como o prelúdio de dissensões mais sérias entre os liberalismos no interior do Império português. Em 18 de fevereiro de 1821, a Junta Provincial havia instado que as Cortes de Lisboa enviasse novas expedições para a defesa da província, pois, naquele momento, se sentia na obrigação de estar protegida caso o Rio de Janeiro reagisse contra as decisões implementadas. Entretanto, ao se ter informações em julho que um reforço militar de 1.184 homens partiu de Portugal em direção à Bahia, muitos reconheciam que a conjuntura inicial havia se alterado a tal medida que a mesma força militar de protetora passara, então, a ser reputada como ameaça premente. ${ }^{28} 0$ Rio de Janeiro não representava mais tanto perigo, seja porque os principais habitantes juraram acatar e defender a constituição, seja pelo fato de d. João VI ter retornado ao seu antigo centro de poder, deixando no Brasil o príncipe regente $d$. Pedro o qual - por razões que futuramente se mostrariam estratégicas - revelava-se muito constitucional. ${ }^{29}$ Por isso, enquanto na província os defensores do liberalismo lusitano comemoravam, uma parcela importante dos baianos revelava-se impaciente com a soberba do projeto das Cortes. Nos quartéis, as tensões passaram a ser extravasadas por meios de violentos confrontos envolvendo soldados europeus e os nascidos na América. Tão melindrosa já se manifestava as dissensões que, em 12 de julho, o cônsul Guinebaud anotou: "Não fora a firmeza do coronel comandante do batalhão 12, composto por 400 portugueses, soldados da Europa, 
30

Apud ARAÚJO, Ubiratan Castro de. A Guerra da Bahia. Salvador: Ceao/UFBA, 2001 (Série Capítulos). p.30-31.

\section{1}

As "Cortes Gerais, Extraordinárias e Constituintes da Nação Portuguesa", instaladas em 26 de janeiro de 1821, iniciaram seus trabalhos com cem deputados do Reino de Portugal. A partir de um processo eleitoral com vários ciclos eletivos, as províncias do Brasil elegeram 94 deputados, entre efetivos e suplentes. Serve como exemplo das dificuldades que algumas provincias encontraram para cumprir todas as etapas desse processo o fato da Bahia só ter conseguido concluir suas eleições em 2 de setembro. Assim mesmo, o representante da comarca de Jacobina não foi enviado a Lisboa por não ter conseguido concluir a eleição em tempo hábil. Portanto, quando o decreto de 29 de setembro começou a ser discutido no Congresso, os representantes das diversas províncias do Brasil ainda não haviam chegado. Todavia, quando o projeto foi submetido à aprovação, os deputados pernambucanos e fluminenses já estavam integrados às Cortes, mas nem por isso tiveram direito de reaver a discussão. BERBEL, Márcia Regina. A nação como artefato: deputados do Brasil nas cortes portuguesas (1821-1822). São Paulo: Hucitec, 1999. Para os dados do processo eleitoral na Bahia, ver também WISIAK, Thomas. Itinerário da Bahia na crise do Império luso-brasileiro (1821-1823). In: JANCSÓ, István (Org.). Independência: história e historiografia. São Paulo: Hucitec; Fapesp, 2005.

32

Essa primeira Junta Provisória esteve no comando do governo da província entre 10 de fevereiro de 1821 a $1^{\circ}$ de fevereiro de 1822 , quando ocorreram novas eleições ainda sob a hegemonia das Cortes de Lisboa. Em 6 de setembro de 1822, os agrupamentos dissidentes alinhando-se ao projeto do Centro-Sul instalaram um Conselho Interino de Governo na vila de Cachoeira e passaram a exercê-lo em nome das vilas interioranas e contra as deliberações advindas de Portugal.

33

Continuadas as expedições, foram também presos: o brigadeiro José Tomás Boccaciari; os capitães Luis Antonio da Silva Horta (cavalaria), José António da Fonseca Machado (legião de caçadores) e João de Souza Neto (secretário da inspeção); os tenentes Francisco Rodrigues Gomes de Souza (artilharia) e João Francisco de Oliveira (sota-patrão da Ribeira); o secretário do 10 regimento de $2^{2}$ linha, Francisco José da Silva Castro; o feitor da alfândega José Soares, o cadete Inácio de Matos Teles de Menezes e João Carneiro da Silva Rego. Cf. SILVA, Ignácio Acciol de Cerqueira e. Memórias Históricas e Politicas da Provincia da Bahia. Anotado por Braz do Amaral. Bahia: Imprensa Oficial do Estado, v.3, p.289-292 e AMARAL, Braz do. História da Independência na Bahia. Salvador: Progresso, 1957. p.39-40. uma nova revolução teria eclodido, o governo teria sido parcialmente renovado e a República proclamada pelos brasileiros". 30

A rapidez das mudanças conjunturais ampliava a provisoriedade política então experimentada. Em fins de outubro foram difundidas as linhas gerais de polêmico decreto que o Soberano Congresso enviou para ser cumprido nas províncias do Brasil. Baseando-se em um projeto aprovado pelos deputados portugueses, em 29 de setembro de 1821, essa resolução, dentre outras questões, abolia a regência de d. Pedro - o qual deveria seguir para Europa -, criava juntas provisórias independentes entre si e sujeitas às Cortes e ao governo de Lisboa e, sobretudo, definia o estabelecimento de governadores das armas de nomeação e subordinação adstritas exclusivamente às Cortes e a el-rei. Ao ser divulgado nas províncias, suas diretrizes serviram aos fins mais diversos, menos inviabilizar politicamente a regência do príncipe de Bragança no Brasil. ${ }^{31}$

No que concerne à Bahia, as primeiras informações sobre o decreto das Cortes ampliaram ainda mais as rivalidades entre os portugueses europeus e americanos, pois o cumprimento do mesmo implicaria em redução da autonomia não apenas para a província, mas para o Brasil como um todo. Contrafeitos a ampla hegemonia exercida pelos lusitanos nos dois lados do Atlântico, um grupo de militares e civis ocupou, em 3 de novembro, o prédio da Câmara Municipal de Salvador e passou a exigir que os membros da Junta ali reunidos renunciassem imediatamente as funções governativas e convocassem novas eleições para a administração provincial. 32 Não obstante o impacto daquela ação, os dissidentes não traziam consigo forças suficientes para concretizar seus objetivos haja vista que nem mesmo as tropas subordinadas aos oficiais presentes no movimento compareceram ao evento. Em contrapartida, o batalhão de infantaria n. 12 - formado exclusivamente por europeus - tentou desbaratar a sublevação. Em pouco tempo, as forças legalistas, em uma ação bem coordenada, não apenas livraram a Junta como capturaram várias lideranças militares que, segundo se afirmaria, coordenavam o movimento.

Entre os encarcerados encontravam-se os tenentes-coronéis José Egídio Gordilho de Barbuda e Felisberto Gomes Caldeira; os majores Elói Pessoa da Silva, José Gabriel da Silva Daltro e José Maria da Silva Torres; o capitão João Antônio Maia e o coronel ajudante de ordens Salvador Pereira Costa. Preocupada com a manutenção destes prisioneiros políticos na Bahia, a Junta Governativa decidiu remetê-los a Lisboa. A justificativa para essa deportação não deixa de ser sintomática de uma nova conformação política que gradativamente parecia promover uma articulação passando pelo o envolvimento de outras provincias, uma vez que sobre estes dissidentes recaia a acusação de pretenderem separar o Brasil de Portugal. ${ }^{33}$ Mesmo considerando que nem para a deposição do governo esse movimento conseguira reunir todas as condições necessárias, a simples menção de uma ambição desta envergadura atesta que sua possibilidade era real e, por isso, merecia a atenção dos contemporâneos. Além do mais, com as prisões e perseguições efetuadas, o alarma tomou conta da cidade, contribuindo para que diversas famílias deixassem suas ocupações e casas para darem início a primeira de uma série de emigrações que, nos meses subseqüentes, iria deslocar cada vez mais dissidentes para o Recôncavo baiano.

Na perspectiva de acalmar os ânimos, e simultaneamente desqualificar os que consideravam sediciosos, a Junta Provisória lançou aos habitantes da capital uma proclamação na qual acusava os arquitetos da malfadada desti- 
34

SILVA, Ignácio Accioli de Cerqueira e. Memórias Históricas e Politicas da Província da Bahia. Anotado por Braz do Amaral. Bahia: Imprensa Oficial do Estado, v.3, p.291-292, nota 23.

35

SOUZA FILHO, Argemiro Ribeiro de. A Guerra de Independência na Bahia: Manifestações políticas e violência na formação do Estado nacional (Rio de Contas e Caetité). Dissertação (Mestrado em História), Faculdade de Filosofia, Letras e Ciências Humanas, Universidade Federal da Bahia, Salvador, 2003.

\section{6}

Guardando alguma semelhança com o ensaio de sedição de 1798, o agrupamento ao qual pertencia João Crioulo parece ter mesclado o uso da propaganda com a ação política. Segundo Accioli, dois dias antes do movimento de 3 de novembro, proclamações foram afixadas em diferentes partes da capital baiana, "e principalmente nos aquartelamentos", com o objetivo de convencer a tropa e povo a expulsarem a Junta Provisional. Mesmo com importantes lideranças na cadeia e outras sendo procuradas pelos agentes repressivos do governo, a prática e propaganda política continuavam. SILVA, Ignácio Accioli de Cerqueira e. Op.Cit., p.289.

37

Dentre os presos deportados, o capitão José António da Fonseca Machado suicidou-se ao chegar a Lisboa e o brigadeiro José Tomás Boccaciari atirou-se ao mar quando a embarcação que o conduzia entrava no rio Tejo. Os demais presos parecem ter suportado a pressão e, finalmente, foram absolvidos pelas Cortes de Lisboa em abril de 1822. Cf. SILVA, Ignácio Accioli de Cerqueira e. Op.Cit., p.289-292 e AMARAL, Braz do. História da Independência na Bahia. Salvador: Progresso, 1957. p.57, nota 9. 38

SILVA, Ignácio Accioli de Cerqueira e. Op.Cit., p.289 (Grifos do autor). Braz do Amaral afirmou que o major Eloi Pessoa da Silva havia começado a redigir uma manifesto mas a sua prisão impediu que esse documento fosse concluido. Ao que tudo indica, havia outros implicados capazes de dar continuidade a contrapropaganda ao governo. AMARAL, Braz do. Op.Cit., p.40. tuição de serem "uns perdidos na opinião pública", cuja organização reunira tão-somente "alguma gente da plebe, raros oficiais de linha e pouquíssimos paisanos sem representação civil".34 Embora distorcesse os fatos quando deliberadamente reduzia ao mínimo a presença dos militares e eliminava a dos demais funcionários da administração no movimento conspiratório, esse rol de culpados fortalece a hipótese de que na América portuguesa de princípios dos anos 1820 diversos extratos sociais estiveram comprometidos com a política. Admite-se, aqui, que a análise de confrontos como estes são relevantes não apenas por confirmarem a existência de outros projetos políticos no interior da Revolução Constitucionalista, mas também porque trazem à tona alguns termos que emolduraram as relações politico-sociais na Bahia ao longo de todo o decênio. De fato, ao combaterem os perigos da "anarquia", dos "partidos" e dos "perturbadores do sossego público",35 as autoridades constituidas deixaram a descoberto os seus temores frente a uma transformação social que extrapolasse os limites do constitucionalismo português.

0 prolongamento dessa discussão tornou-se necessário devido às relações que ela mantém com as novas prisões de dezembro de 1821 do escravo João Crioulo e do pardo Francisco Antonio de Souza, bem como com a existência dos manifestos políticos mencionados, cuja autoria foi atribuída ao cadete João Primo. Esses personagens e documentos colocavam a Junta Provisional diante de uma incômoda resposta política, uma contrapropaganda às mensagens divulgadas pelo governo aos baianos, pois o cadete João Primo, que anos mais tarde também exerceria sua liderança nos movimentos federalistas na Bahia, havia sido um participe importante na frustrada tentativa de destituição da Junta. ${ }^{36}$ Todavia, ao contrário de outras lideranças, escapara à prisão e à desesperação de ser remetido a Portugal, que para alguns já causava verdadeiro pavor. ${ }^{37}$ Mutatis mutandis, o comportamento radical de João Primo era já demasiadamente conhecido em 1821, tanto que, quando dos acontecimentos de 3 de novembro, um grupo de portugueses que chegara à praça junto com as tropas legalistas, prevendo que o movimento seria subjugado, passou a gritar: "morra João Primo [...], fora revolucionários!".38

Após as prisões do escravo João e a do pardo Francisco, a Junta Provisional deu conhecimento ao ouvidor geral do crime, desembargador José Gonçalves Marques, para que procedesse a devassa sobre o conteúdo e a procedência daqueles escritos que, segundo afirmava, pretendiam "amotinar os povos". Reproduzidos ao longo dos autos, os papéis distribuidos "dispersamente" pela capital, constituiam, de fato, um ataque direto aos integrantes do governo. Embora não atacasse as Cortes lisboeta, um dos documentos apregoava:

Todo Cidadão é livre quando nasce, e um dos elementos da liberdade é o direito que cada um tem para manifestar a sua opinião contra a tirania [...] Senhores Proclamadores a causa que nos obrigastes no dia 3 do corrente mês [novembro] tentar solenemente reconquistar os nossos perdidos Direitos, vós não podeis deixar de ter em consideração! A ordem atual das coisas, e a falta de exatidão em vossa conduta, nos dão a força natural apoiada com sentimentos Constitucionais! Nós, ouvindo às queixas e ao descontentamento geral dos Habitantes desta Província, obramos como interpretes da vontade dos Cidadãos protegidos pelo Estandarte Municipal e pelo Direito humano! [...] Proclamadores, negareis estas verdades? Dizei-nos se os Povos tiveram poder para obrigar a Sua Majestade Fidelíssima [d. João VI]... pela Constituição, por que não terão direito para depor péssimos membros da Junta Provisional, e logo depositar a sua Autoridade em beneméritos 
39

Cidadãos beneméritos e verdadeiros

Constitucionais respondem às fabulosas Proclamações dos agonizantes Bachás..! SENHORES DÉSPOTAS DO NOVO MODELO! Devassa de escritos inflamatórios e Sediciosos encontrados em mãos de João Crioulo, escravo de Antonio José Pereira Rocha, e Francisco Antonio de Souza. Cópias de devassas - processos datilografados. APEB. Seção Colonial e Provincial. Ano: 1821-1823. Maço: 6023. (Grifos meus).

40

Devassa de escritos inflamatórios e Sediciosos encontrados em mãos de João Crioulo escravo de Antônio José Pereira Rocha, e Francisco Antonio de Souza. Cópias de devassas - processos datilografados. APEB. Seção Colonial e Provincial. Ano 1821-1823. Maço 6023.

\section{1}

Devassa de escritos inflamatórios e Sediciosos... Maço: 6023. A documentação consultada, até aqui, não permitiu também conhecer quanto tempo estes individuos permaneceram presos.
Portugueses eleitos pelos Eleitores de Paróquia [...]? Um homem tem direito de matar a quem o quer privar da vida; e os Povos não hão de ter Direito de livrarse de meia dúzia de perversos, que atacam os Direitos e as relações sociais? Vós assentais que é a raça escolhida para nos governar, e que as outras classes são raças condenadas a vos obedecerem; e com essas lindas idéias quereis que o Povo, que vos aborrece, tome partido para vós, assegurem em vossas trementes e rapinarias mãos a vara de ferro com que o tendes regido! Sim, vós quereis que essa vara abrasada incendeie a Província para mais de uma guerra civil! Sabeis vós, nefandos Proclamadores, até aonde chegará este flagelo da humanidade! 39

Essa passagem sintetiza o profundo aprendizado político, de caráter radical, ainda que fortemente atado aos Direitos do Homem e do Cidadão, característico da Era das Revoluções, que, de forma inequívoca, manifestavam-se em território baiano. Ainda que não mencionasse diretamente a soberania popular, lembrava ao público que "os Povos tiveram poder para obrigar" a el-rei a jurar a constituição. Com o mesmo estilo indireto, o manifesto trazia à tona as delicadas questões envolvendo as noções de raça e classe social relacionadas à luta política. Por fim, alertava contra os perigos de se estabelecer na província "uma guerra civil", deixando entrevisto que a partir dali várias possibilidades estariam abertas. Será que o governo poderia aí também vislumbrar outro indício de que o cadete João Primo e seus parceiros abriam caminho para a defesa da separação definitiva entre o Brasil e Portugal? Se relacionarmos com a acusação imputada aos demais dissidentes enviados a Lisboa, é possivel que a resposta sobre esta questão seja positiva.

Confrontado com a situação, em 10 de dezembro o ouvidor geral do crime ordenou a abertura de uma devassa, sendo ouvidas trinta testemunhas. Vários depoentes, ao depararem-se com os escritos que Ihes foram apresentados, afiançaram estar diante da "letra e firma de João Primo". Outros foram além e afirmaram possuir conhecimentos anteriores de parte das idéias ali contidas pois presenciaram o próprio cadete defendê-las. 40 Os rumos das averiguações prosseguiam avançados. Porém, o tempo não era o mais propício às investigações prolongadas, já que a provisoriedade política persistia. Novas informações, gradativamente, davam conta das mudanças na ordem política passadas nas Cortes de Lisboa; enquanto no Brasil, importantes províncias demonstravam não aceitar de Portugal nada menos do que uma autêntica autonomia. Nesse interim, os baianos souberam que as Cortes decidiram pela realização de nova eleição para as juntas provinciais. Essa resolução legitimava, mesmo que extra-oficialmente, as reivindicações defendidas pelo cadete João Primo e os demais dissidentes. Marcadas as eleições para 31 de janeiro de 1822, os responsáveis pela devassa em andamento viram-se, por certo, na necessidade de encontrar uma solução que não se chocasse com a nova conjuntura. Assim, em 8 de janeiro, o ouvidor ditou ordens para que o escravo João Crioulo e o pardo Francisco Antonio de Souza fossem "averbados no rol dos culpados e recomendados prisão". Disposto sob medida, o veredicto atingia os que menos poderiam se defender no interior de uma sociedade arraigada a instituição escravista. E nem, ao menos, esclarecia até que ponto a junção política entre senhores e escravos poderia ter sido novamente restabelecida na província. Ademais, o pardo Francisco e principalmente o escravo João eram leitores? Conheciam as idéias contidas na contrapropaganda ao governo? Ou teriam sido apenas mensageiros contatados para a propaganda política? Infelizmente, estas questões não puderam ser aqui esclarecidas. ${ }^{41}$ 
42

Sobre os processos destas eleições e os escolhidos para a administração provincial, ver WISIAK, Thomas. A Nação partida ao meio: tendências políticas na Bahia na crise do Império Lusobrasileiro. Dissertação (Mestrado em HIstória), Universidade de São Paulo, 2001.

43

BANDEIRA, Luiz Alberto Moniz. 0 feudo: A Casa da Torre de Garcia d'Ávila: da conquista dos sertões à independência do Brasil. Rio de Janeiro: Civilização Brasileira. 2000. p. 388.

44

A representação data de 22 de fevereiro de 1822 se encontra reproduzida em AMARAL, Braz do. História da Independência na Bahia. Salvador: Progresso, 1957. p.144-145.

\section{5}

Cf. FERNANDES, Florestan. A sociedade escravista no Brasil. In: IANNI, Octávio (Org.). Florestan Fernandes: sociologia crítica e militante. São Paulo: Ed. Expressão popular, 2004. p. 367.
Com vistas à reeleição, os integrantes da antiga Junta empenharam-se para ser reconduzidos à administração. No dia da eleição, porém, os eleitores exerceram ao limite o poder delegativo e, assim, renovaram todo o governo. Não deixa de ser igualmente interessante o fato de que entre os sete membros escolhidos para o poder provincial apenas um tenha nascido em Portugal. ${ }^{42} \mathrm{Em}$ que se considere o novo arranjo institucional, as relações dos baianos para com os defensores de antiga metrópole continuaram a deteriorar-se. A crise política, por fim, adquiriu contornos decisivos em fevereiro de 1822, quando se soube que o militar nomeado pelas Cortes e el-rei para o governo das armas era ninguém menos que o brigadeiro Luís Inácio Madeira de Mello que, até então, comandava o batalhão de infantaria n. 12. Desde julho do ano anterior, esse militar tornara-se o maior defensor dos portugueses, pois fora um dos principais protagonistas a impedir que outros projetos políticos mudassem os rumos do movimento constitucionalista na Bahia. Em contrapartida, muitos baianos viam na sua designação a prova irrefutável de desprezo que o projeto das Cortes reservava não apenas para o território baiano, mas para o Brasil como um todo.

Ao debaterem a nomeação, os vereadores quiseram retardar ou mesmo impedir a posse do brigadeiro, lembrando inclusive que na qualidade de órgão municipal e congresso do povo deviam decidir-se pelo que fosse melhor para o governo da província. ${ }^{43}$ Os militares também se posicionavam e, enquanto as tropas européias colocavam-se à disposição do brigadeiro português, os corpos de $1^{\circ}$ regimento de infantaria, artilharia e legião de caçadores recusavam terminantemente que o comando deixasse de pertencer a um filho da terra, no caso, ao brigadeiro Manuel Pedro de Freitas Guimarães. As provocações avolumaram-se e, entre os dias 18 e 21 de fevereiro, a cidade de Salvador foi sacudida por violentos combates envolvendo militares e civis. Mantidas suas melhores condições, os soldados europeus forçaram a retirada dos batalhões resistentes para o Recôncavo; muitas outras famílias procuraram o mesmo destino e a capital caiu sob o domínio das tropas do brigadeiro Madeira de Mello. Contudo, as graves divergências e os enfrentamentos continuados deram origem à guerra de independência e, por fim, à expulsão definitiva das tropas lusitanas da província, em 2 de julho de 1823.

Observa-se, então, que as dissensões armadas na capital, em fins de 1821 e princípios de 1822, abriram, em definitivo, a possibilidade de serem levados adiante planos políticos mais audaciosos. Dentre os "projetos" favorecidos pelas disputas na província, consta que, logo após a rendição da cidade, uma denúncia, em forma de representação assinada por 848 "negociantes, proprietários, militares e [...] cidadãos", informava aos deputados em Lisboa sobre uma provável articulação entre o príncipe d. Pedro e parte dos moradores da capital objetivando "a mais escandalosa cisão entre o Brasil e Portugal".44 Essa nova acusação deveria confirmar as informações da Junta anterior de que a pretensão de se levar a efeito a articulação pela independência política vinha sendo considerada por algum tempo na Bahia.

Por outro lado, não se pode deixar de destacar que no interior das facções em luta havia graves fissuras políticas, como atestam os comportamentos dos dissidentes da Revolução Constitucionalista, e essas divergências não se restringiam apenas a polarização entre portugueses e filhos $d a$ terra. Eram, de fato, muito mais complexas. No âmago de uma sociedade na qual o trabalho escravo se constituía a mola-mestra da acumulação do capital mercantill, ${ }^{45}$ a classe senhorial não podia esquecer-se dos dife- 
46

Apud SILVA, Ignácio Accioli de Cerqueira e. Memórias Históricas e Politicas da Província da Bahia. Anotado por Braz do Amaral. Bahia: Imprensa Oficial do Estado, v.3, p.353, nota 50 (Grifos meus).

\section{7}

Ibidem.

48

MORAIS, José Geraldo Vinci de; REGO, José Márcio Rego. Conversa com historiadores brasileiros. [entrevistas concedida por] João José Reis. São Paulo: Ed. 34, 2002. p. 328. Ver também SILVA, Eduardo; REIS, João José. Negociação e conflito: a resistência negra no Brasil escravista. São Paulo: Companhia das Letras, 1989.

\section{9}

FRANÇA, António d'Oliveira Pinto da (Org.). Cartas baianas, 1821-1824: subsidios para o estudo dos problemas da opção na independência brasileira. São Paulo: Nacional; Rio de Janeiro: Núcleo Editorial da Universidade do Estado do Rio de Janeiro, 1980. p. 36. rentes segmentos sociais que em 1798 tencionaram revolucionar a base social e material daquela sociedade; acompanhava igualmente a série de revoltas escravas que desde o ano de 1807 ameaçavam a paz dos senhores no entorno da capital e nas áreas do Recôncavo e, finalmente, não seria prudente de sua parte negligenciar a fato dos revolucionários pernambucanos de 1817 terem considerado, por algum tempo, a capitania baiana como área de influência para seus projetos.

Nesse sentido, existia tanto da parte do governo da capital quando da resistência que a partir do Recôncavo começava a organizar-se a preocupação para que não saíssem fortalecidos os interesses dos segmentos subalternos da sociedade escravista na Bahia. Grosso modo, escravos africanos e crioulos, e uma espessa população mestiça e pobre conformaram os segmentos sociais que, na perspectiva das autoridades, exigiriam naqueles anos o maior controle. Assim, em $1^{\circ}$ de julho de 1822, quando os conflitos entre lusitanos e filhos da terra extrapolavam o perímetro da capital, a Junta Provincial cuidou de precaver ao brigadeiro Luís Inácio Madeira de Mello sobre o "quanto impolítica e tremenda seria para a segurança de toda esta província a tentativa de fazer o Recôncavo, recheado de castas perigosissimas, teatro de uma guerra exterminadora". 46 Sem demonstrar preocupação aparente, o militar português considerou ser este um problema para a classe senhorial rebelde solucionar, já que era portadora do "instrumento da desgraça" e, como ela se esquecesse que muitos dos escravos residiam no interior das suas casas, agiam como se não percebessem que quaisquer exemplos subversivos para com as autoridades constituídas estavam sujeitos a propiciar a "imoralidade" dos cativos, os quais aderindo à rebelião em curso, bem poderiam reduzir "a província a teatro da mais sanguinolenta e horrorosa cena". 47

Entretanto, nos primeiros decênios do Oitocentos a figura legal do escravo na América portuguesa convivia com uma simbologia que tendia a discriminá-lo simultaneamente como um inimigo doméstico e um inimigo público. E era justamente por manter um ambíguo convivio de vasta experiência com antagonistas desta natureza que a classe senhorial pressupunha conhecer até que ponto o perigo rondava-a. Nesse sentido, João José Reis coloca bem a questão ao enfatizar que "o conflito é inerente à relação entre escravos e senhores", enquanto "a negociação é uma estratégia de resistência escrava, tanto quanto de dominação senhorial". Afinal de contas, a articulação entre estes dois pólos é que garantia um mínimo de harmonia entre as partes. ${ }^{48}$

Por experimentar em princípios de 1822 um cenário político inédito, mais também indeciso, as classes diretivas, tanto na capital, quanto no Recôncavo, não estavam desatentas à possibilidade do conceito liberdade, em seu sentido sócio-político, atingir a ordem societária escravista ou que favorecesse a uma revolução de caráter popular. Dai as constantes referências das autoridades quanto à fermentação política propiciada por facções anarquistas ou republicanas com articulações na capital e em algumas vilas do interior. No que se refere à condição dos escravos, em abril de 1822, a senhora do engenho Aramaré, Maria Bárbara Garcez Pinto da França, havia registrado que "a crioulada de Cachoeira", se aproveitando da convocação de Cortes Gerais, chegou a enviar "requerimentos para serem livres".49 Conquanto, para ela, e mesmo para uma parcela importante dos segmentos dominantes da Bahia, o perigo real contra a ordem, inclusive a escravista, residia não nos cativos, ainda que estes tivessem nascido no Brasil, mas no 
50

A categoria histórica de "classe social" aqui mencionada tem como fundamento as proposições enunciadas por THOMPSON, Edward Paul, o qual admitia o critério de experiência pautando a consciência de classes. La sociedad inglesa del siglo XVIII: ¿luta de classes sin classes? In: Tradición, revuelta y consciencia de classe: Estudios sobre la crisis de la sociedad preindustrial. Prólogo de Josep Fontana. Barcelona: Editorial Crítica, 1984. p.13-61.

51

Por essa época, a cidade de Salvador era uma dos maiores aglomerados populacionais de toda a América. Cf. MATTOSO, Kátia M. de Queirós. Bahia, século XIX: uma província no Império. Rio de Janeiro: Nova Fronteira, 1992. amplo contingente envolvendo pardos e crioulos, dentre os quais, muitos dispostos a elaborarem ou encamparem projetos que lhes assegurassem uma maior inserção político-social.

De fato, passados quase três centúrias de intensa miscigenação entre europeus, ameríndios e africanos, nenhum outro segmento social tornouse tão representativo no Brasil como os que se situavam entre a classe senhorial e os escravos, cuja clivagem étnica comportava majoritariamente crioulos, cabras, mulatos e pardos. $E_{1}$ em se tratando de descortinar os elementos ideológicos, tanto as autoridades interioranas como as que dominavam na capital viam-se forçadas a considerar, para os cálculos políticos e sociais a ser implementados, a preponderância daquela camada societária. Mesmo porque, a crise irredutivel do Antigo Regime, com seus vastos privilégios, mormente a reserva dos melhores empregos públicos para os bem-nascidos, havia atingido em cheio as camadas intermediárias da sociedade escravista. Com poucas alternativas para escapar à lógica asfixiante de um sistema hierárquico em ruínas, tornava-se factível aos homens e as mulheres desse segmento societário a criação de vínculos identitários, de redes de sociabilidade que, apesar das contradições internas, já traziam para a prática cotidiana elementos que permitem uma análise pautada na consciência de "classe social". 50

\section{Manifestações antilusitanas na cidade da Bahia}

Em 8 de novembro tivera lugar a batalha de Pirajá, reconhecidamente o mais violento e importante combate entre dois conjuntos de tropas que levaram a efeito a Guerra de Independência Dentre os contendores, encontrava-se, de um lado, o Exército Português, comandado por Madeira de Mello e, no seu flanco, o Exército Pacificador, composto por agrupamentos militares de várias províncias subordinados ao oficial francês Pedro Labatut, contratado por d. Pedro, que aguardava ser brevemente coroado imperador constitucional do Brasil.

Paralelo à coroação imperial do herdeiro de Bragança, ocorrida no Rio de Janeiro em $1^{\circ}$ de dezembro de 1822, muitos habitantes da capital baiana já sentiam o desconforto que o cerco coordenado pelo Exército Pacificador, e sustentado pelo restante da província, Ihes causavam. A falta de gêneros alimentícios e, por conseqüência, a grande carestia eram, com efeito, as principais penúrias experimentadas. Sem muito poder de manobra, as tropas portuguesas percebiam quão complicado era manter a ordem no interior de uma urbe sem dispor de uma base consensual segura entre o conjunto da população. ${ }^{51}$ Não obstante o brigadeiro Madeira de Mello ter postergado o quanto pôde as declarações oficiais que Ihe permitia dispor da capital como uma praça de guerra e em estado de sítio, havia, ao final daquele ano, muita preocupação com o comportamento dos habitantes sobretudo em se tratando das classes populares.

Nestas circunstâncias e em pleno 24 de dezembro, chegou às mãos do já experimentado ouvidor geral do crime e desembargador José Gonçalves Marques a denúncia de uma arruaça envolvendo mata-maroto. Na noite anterior, haviam sido conduzidos à Cadeia da Relação, os presos milicianos Luís Gonzaga, do $5^{\circ}$ regimento de milícias, João Maurício, do $4^{\circ}$ regimento, Daniel Alexandrino, do $2^{\circ}$ regimento, José Antonio de Azevedo, da artilharia miliciana, e Izidro dos Santos, considerado desertor do mencionado $5^{\circ}$ regimento. Ao lado destes, encontravam-se os paisanos Manoel Luis, Francisco 
É interessante notar que, a exceção do $4^{\circ}$ regimento composto por homens pardos, as demais unidades militares mencionadas eram formadas por homens brancos. Mata-Maroto: Processo contra militares e paisanos acusados de atacar o cabo Melquíades José Dias Maciera, gritando "mata que é maroto". Cópias de devassas - processos datilografados. APEB. Seção Colonial e Provincial. Ano: 1821-1823. Maço: 6023. 53

Infelizmente, os autos não indicam o número do regimento de milícias ao qual pertencia o cabo Melquiades, nem maiores informações sobre o batalhão n. 1 que o protegeu. Deste último agrupamento, sabe-se, contudo, que seus integrantes pertenciam à brigada do batalhão $n$. 1, o que se deduz serem militares europeus da tropa paga.

54

Mata-Maroto: Processo contra militares e paisanos..., Maço: 6023.

55

Mata-Maroto: Processo contra militares e paisanos..., Maço: 6023. da Silva, José Pedro e Zeferino Brás. Embora o local de origem destes presos não tenha sido mencionado, tudo leva a acreditar que eram baianos, ou pelos menos, que nasceram no Brasil. 52

Registrou-se nos autos do processo que estando os militares e seus companheiros reunidos, "à Rua do Caquende, em sociedades e ajuntamento com toques de violas", ao avistarem o cabo de esquadra do regimento de milícias, Melquiades José Dias Macieira, gritaram "mata que é maroto", mas o mesmo conseguiu fugir. Não demorou, porém, e o cabo Macieira, acompanhado por uma patrulha do batalhão n. 1, retornou ao lugar em que dizia ter sido agredido. 53 Ao reencontrar no "mesmo sítio [...] um ajuntamento de homens, tocando uns e outros aos pés", o oficial "queixoso" reconheceu-Ihe como sendo aquele o grupo que o havia perseguido. Rapidamente violeiros e convivas viram-se cercados e a estes, bem como aos que estavam no interior da residência, foram dadas vozes de prisão. A eficiência da operação militar, no entanto, não se realizou por completo e, pela "porta do quintal", alguns indivíduos conseguiram evadir-se. Adiante (em 10/01/1823), o sargento de milícia, Luis Ferreira Sobral, homem branco, casado e com 31 anos de idade, foi chamado na condição de primeira testemunha sobre aquele "motim". Na ocasião, certificou as autoridades que, como um dos integrantes do patrulhamento, partiu dele a ordem de prisão aos implicados, sendo também o responsável pelas buscas no interior da residência, que resultou na apreensão de "uma faca de ponta metida em uma bainha" de couro achada em cima de uma mesa. ${ }^{54}$

Sem alterar o perfil das testemunhas, o ouvidor inquiriu mais três patrulheiros que integraram a intervenção policial-militar. Em seus depoimentos, todos confirmaram a versão relativa ao comportamento do cabo Macieira na noite de 23 de dezembro, conquanto um deles apresentasse uma versão um pouco diferente sob a forma como foi encontrada o único instrumento que podia complicar a situação dos acusados. Segundo o também sargento Antonio Joaquim José Maria Luz, branco, solteiro, 31 anos, ao tempo em que se procederam as prisões, apareceu o seu oficial de brigada com uma faca, a qual dissera ter "tomado da mão de um dos ditos presos". Essa afirmação, embora não fosse contrastada ao longo do inquérito, punha em dúvida o argumento anterior.

0 certo é que as autoridades prosseguiram com as investigações e, finalmente, convocaram um civil para depor. Dessa maneira, Joaquim José de Santa'Anna, cabra forro, com ofício de aparelhador, 50 anos, ofereceu uma explicação bem controversa para o ocorrido. Embora não se apresentasse na condição de testemunha ocular, Joaquim sabia, "por ouvir dizer", que estando os sumariados à porta de uma casa quando por ali, "passara uma mulher acompanhada de um homem" e, como estes não Ihes cumprimentaram, os acusados "Ihes disseram graças", sendo, em seguida, presos. .5 Casos como estes, são interessantes à medida que permitem observar a persistência de sentimentos antilusitanos na cidade ocupada. Da mesma forma que não é descabido pensar que muitos portugueses, habitando o interior, desejaram se engajar na defesa do projeto político das Cortes, mas, com o tempo, as condições objetivas Ihes exigiram maior prudência. Também é factivel deduzir, com melhor margem de segurança, que uma proporção ainda maior de filhos da terra pretendeu combater as tropas lusitanas ou mesmo escapar para outras paragens do interior, porém muitos tiveram que permanecer na capital assediada, aguardando o completo desfecho da guerra. 
56

Resposta justificada de Miguel Calmon de Pin e Almeida à declaração franca que faz o general Labatut da sua conduta, enquanto comandou o Exército Imperial e Pacificador. Revista do Instituto Geográfico e Histórico da Bahia, n. 65, Bahia, 1939, anexo doc. 20. p.120-121.
Nesse aspecto, reafirma-se que no interior da sociedade escravista baiana todos os segmentos sociais desempenhavam funções inerentes ao equilíbrio e à manutenção do sistema. Apesar da Revolução Liberal, as exigências da guerra continuaram subordinadas, ao menos na visão dos seus principais dirigentes, aos velhos princípios sociais. Assim, o Exército português procurou controlar a população residente na capital. Mas, como seu domínio esteve longe de ser total, a fuga foi acessivel à maioria dos que dispunha das condições físicas e dos recursos financeiros necessários a empreitada de abandonar lares e afazeres. Por outro lado, a resistência concentrada no Recôncavo soube também aliciar para sua causa quadros políticos e um sem-número de indivíduos dotados de conhecimentos técnicos, mormente aqueles que serviam ou estavam aptos para o ingresso nas forças militares.

Todavia, parte considerável da população civil de Salvador acabou submetida, de certa forma, às condições de cerceamento impostas por ambos os Exércitos. Somente em 22 de janeiro de 1823, quando o espectro da fome rondava a cidade assediada pelas tropas fiéis a d. Pedro I, o brigadeiro Madeira de Mello liberou a saída para o interior da província de velhos, mulheres e meninos. Em oposição a essa medida, e mais ainda aos paisanos nela envolvida, o general Labatut comunicou ao Conselho Interino em Cachoeira que seus oficiais, com tropas estacionadas nos limites de Salvador, tinham ordens para fazer retornar ao local de origem qualquer um que intentasse deixar a capital, pois isso, segundo avaliava, apressaria a evasão das tropas lusitanas. Nos termos desse ofício, nenhuma condescendência especial foi assegurada, permitindo, então, deduzir que a maioria dos desafortunados que, por terra, tentaram deixar Salvador viram-se obrigados a retroceder com suas queixas e necessidades para uma cidade privada de alimentos. ${ }^{56} \mathrm{~A}$ rigor, a logística da guerra se impunha sobre os demais direitos. Os civis, mesmos os totalmente indefesos, encontravam-se, naquelas circunstâncias, mais suscetiveis às pressões e manipulações pois eram tratados apenas como um recurso a mais que, em última instância, poderiam possibilitar vantagens sobre o inimigo.

Sobre a conclusão do processo de acusação de mata-maroto, verificase que nem a prevalência da guerra, nem a carestia e ameaça de fome que a acompanhou foram impeditivas para que milicianos, desertores e outros conhecidos se reunissem para celebrar, de quando em vez, suas alegrias ou quiçá afogar as mágoas que os conflitos entre Portugal e Brasil suscitava. Por outro lado, a junção de pessoas pelas freguesias de Salvador pode muito bem ter sido espontânea, própria da sociabilidade caracteristica entre amigos e vizinhos que viveram na Bahia oitocentista. Mas, como desde o período colonial as autoridades atuaram no sentido de censurar as manifestações da cultura popular, especialmente em época de festejos como era a proximidade do Natal e final de ano, o cabo Melquiades pode ter encontrado motivos para se sentir incomodado com a folgança promovida pelos filhos da terra.

De outra forma, por estarem reunidos aos sons das violas, e quiçá degustando alguma bebida, estes homens podiam mesmo fazer troças aos que se sentiam como os maiores da terra. Eles podiam, ainda, reportar-se aos últimos assuntos políticos e mesmo expressar preferências a algum projeto em particular. Então, é provável que em circunstâncias, ao menos, similares, apareceu-Ihes o cabo Melquiades, um oficial de baixa patente, e reconhecidamente lusitano. Se este militar estivesse sozinho, o que fazia ali 
57

Mata-Maroto: Processo contra militares e paisanos acusados de atacar o cabo Melquiades José Dias Maciera, gritando "mata que é maroto". Cópias de devassas - processos datilografados. APEB. Seção Colonial e Provincial. Ano: 1821-1823. Maço: 6023.

\section{8}

Apud FRANÇA, António d'Oliveira Pinto da (Org.). Cartas baianas, 1821-1824: subsidios para o estudo dos problemas da opção na independência brasileira. São Paulo: Nacional; Rio de Janeiro: Núcleo Editorial da Universidade do Estado do Rio de Janeiro, 1980. p.35-36. Sobre o episódio ver também, SILVA, Ignácio Accioli de Cerqueira e. Memórias Históricas e Políticas da Província da Bahia. Anotado por Braz do Amaral. Bahia: Imprensa Oficial do Estado, v.3. p.339-340. próximo aos filhos da terra? Possivelmente mais arriscado seria se circulasse em companhia de uma mulher, pois, neste caso, as motivações para as dissensões e os ciúmes, em uma cidade ocupada e obrigada às agruras da guerra, ampliavam-se consideravelmente.

De qualquer forma, o ouvidor Gonçalves Marques pouco pôde ou quis fazer. Em meio a versões divergentes, preferiu outra vez encaminhar a questão pelo modo mais simples. Para tanto, obrigou que fosse preso e averbado no rol dos culpados "o dono e morador da casa onde estava o ajuntamento e foi achada a faca", e se passassem "ordens de soltura quanto aos demais por não ser bastante a queixa do queixoso para prova do motim que denunciou". Decisão negociada, coube ao escrivão notificar que o réu pronunciado, por ser proprietário e residente na referida casa, seria o pardo forro Marcos Pinheiro de Queirós. ${ }^{57}$ Todavia, se este indivíduo, também egresso do mundo da escravidão, chegou a ser preso ou se sofreu qualquer dissabor em razão da sentença do ouvidor geral a documentação analisada não revela.

Sobre as manifestações antilusitanas em Salvador no contexto de crescentes dissensões entre os filhos da terra e as diretrizes políticas das Cortes de Lisboa é relativamente conhecido o episódio ocorrido na capital baiana em 19 de março de 1822. Celebrava-se, então, a festa de São José, venerável de grande consideração na tradição religiosa lusitana. Em seu louvor, os europeus organizaram uma procissão e, para acompanhar o cortejo, convidaram uma guarda da Legião Constitucional Lusitana. Todos se reuniram e ao descerem, em macha solene, a ladeira Conceição da Praia, foram recepcionados com saraivadas de pedras fornecidas por um grupo de negros. Rapidamente, os participantes procuraram dispersar-se, mas poucos escaparam incólumes. Soldados, civis e até imagens apareceram com partes arrebentadas. Um novo destacamento militar foi convocado e, com tiros de mosquetes, garantiu o que restou da profanada celebração. Contudo, ao subirem a ladeira do Taboão, de volta para o quartel, estes mosqueteiros foram igualmente alvejados por outra chuva de pedras. Indignando-se, Madeira de Mello enxergou nas manifestações o propósito de "alguns malvados", que previamente arregimentaram e pagaram determinadas pessoas para atacarem o cortejo. A senhora de engenho Aramaré, no entanto, viu na interpretação do brigadeiro português uma "horrorosa calúnia", complementando em tons denunciantes que "esteve um pobre homem preso vinte dias, pois disseram que ele tinha dado meia pataca a trinta moleques" para realizarem aquelas peripécias. ${ }^{58}$ Razão pela qual, Maria Bárbara preferiu acreditar em ações políticas, ou mesmo em atos espontâneos, levados a termos pelas classes populares. E nisso não deveria estar sozinha.

\section{Conclusão}

Subsistindo apartadas da capital, parte das classes senhoriais aceitou, em principios de 1822, uma aproximação com o Rio de Janeiro com vistas a se antecipar a uma possivel radicalização do processo político em curso, já que tudo Ihes apresentava indefinido. Naquelas circunstâncias, a articulação de uma aliança com o membro da dinastia bragantina ampliou, de forma considerável, a capacidade de resistência dos segmentos dominantes no interior baiano, em detrimento das decisões das Cortes de Lisboa. De resto, a repercussão dessa inovação política na província baiana urdiu, ao menos provisoriamente, uma tessitura ideológica larga o suficiente para congregar 
59

Cf SILVA, Eduardo: REIS, João José. Negociação e conflito: a resistência negra no Brasil escravista. São Paulo: Companhia das Letras, 1989. nas fileiras da resistência os principais estratos sociais contrários à dominação lusitana, incluindo-se ai os que, por razões diversas, continuaram residindo na cidade de Salvador, como parecia ser o caso dos acusados de intentarem o mata-maroto.

A desagregação do Antigo Regime português na Bahia permite analisar o quanto as idéias liberais, com maior ou menor explicitação, foram incorporadas às experiências dos segmentos sociais neste período. Além do mais, o processo de Independência liberou "energias coletivas de difícil controle" que, não raramente, ultrapassaram as graves rivalidades entre lusitanos e filhos da terra, para resvalar em questões ainda mais complexas, como as divisões étnicas, ideológicas, políticas e sociais de uma sociedade em busca de alternativas para conformação de uma nova ordem. ${ }^{59}$

Nessa perspectiva, ao ser convocada para assumir direta ou indiretamente os custos do conflito luso-americano, a plebe urbana de Salvador, assim como os habitantes residentes no interior, dentre os quais muitos reconhecidos pelas autoridades como perturbadores do sossego público, mantiveram suas presenças na cena política. Além do mais, a expulsão das tropas lusitanas, em julho de 1823, não arrefeceu as manifestações turbulentas que se estenderam até, pelo menos, a abdicação de d. Pedro I, aprofundando o aprendizado político cujo ideário nem sempre esteve de acordo com os interesses centrípetos orquestrados no Centro-Sul.

Recebido para publicação em agosto de 2007

Aprovado em março de 2008 